\title{
Article
}

\section{Corporate Social Responsibility and Islamic Financial Institutions (IFIs): Management Perceptions from IFIs in Bahrain}

Aribi, Zakaria and Arun, Thankom Gopinath

Available at http://clok.uclan.ac.uk/12750/

Aribi, Zakaria ORCID: 0000-0001-7772-2341 and Arun, Thankom Gopinath (2014) Corporate Social Responsibility and Islamic Financial Institutions (IFIs): Management Perceptions from IFIs in Bahrain. Journal of Business Ethics, 129 (4). pp. 785-794. ISSN 0167-4544

It is advisable to refer to the publisher's version if you intend to cite from the work. http://dx.doi.org/10.1007/s10551-014-2132-9

For more information about UCLan's research in this area go to http://www.uclan.ac.uk/researchgroups/ and search for <name of research Group>.

For information about Research generally at UCLan please go to http://www.uclan.ac.uk/research/

All outputs in CLoK are protected by Intellectual Property Rights law, including Copyright law. Copyright, IPR and Moral Rights for the works on this site are retained by the individual authors and/or other copyright owners. Terms and conditions for use of this material are defined in the policies page. 


\title{
Corporate Social Responsibility and Islamic Financial Institutions (IFIs): Management Perceptions from IFIs in Bahrain
}

\begin{abstract}
Islamic finance is gaining greater attention in the finance industry, and this paper analyses how Islamic Financial Institutions (IFIs) are responding to the welfare needs of society. Using interview data with managers and content analysis of the disclosures, this study attempts to understand management perceptions of Corporate Social Responsibility (CSR) in IFIs. A thorough understanding of CSR by managers, as evident in the interviews, has not been translated fully into practice. The partial use of IFIs' potential role in social welfare would add further challenges in the era of financialisation.
\end{abstract}

\section{Introduction}

The Islamic Financial Institutions (IFIs) are a fast-growing sector of the global finance industry, and posing challenges to the ways that existing financial institutions are perceived and experienced around the world. IFIs follow a zero-interest approach based on equity and risk sharing and have become a trillion US dollar industry (Sheng and Singh, 2012). These institutions have a unique ethical identity which gives equal importance to social goals and profit, and challenges the conventional bias towards debt instruments in the financial sector. The savings and investments of IFIs are settled by real sector economic activities, which focus on long-term goals rather than the short-term risk-taking decisions which are popular in the financial sector. The fundamental question is how an institution built on Islamic values continues in a "value-free society where economists focused exclusively on the mechanics of economics" (Rice, 1999). However, over the years, changes in the arguments of leading economists have appeared, over the incessant distributional concerns of international development, encouraged by market turbulence. For instance, in a recent essay on 'markets and morality', Bhagwati (2011) has argued that values will determine the player's behaviour in the market place, but further asserts that good policies have "to walk on both legs, positive and normative, and both have to be sound and strong" (p.163). IFIs follow both positive and 
normative traditions; although they are structured around Islamic principles, they follow modern business practices outright. In this paper, we analyse how Corporate Social Responsibility (CSR), a concept defined in a Western context, is consistent with the practices of IFIs.

The social responsibility of corporate institutions and how they respond to the welfare expectations of society are important concerns in modern business. The EU (2011, p.6) defines CSR as the "responsibility of enterprises for their impacts on society" which tacitly infers welfare subtexts in the handling of corporate institutions. The definition further explains that enterprises "should have in place a process to integrate social, environmental, ethical human rights and consumer concerns into their business operations and core strategy in close collaboration with their stakeholders" (p.6). Under CSR, businesses are addressing the needs of a larger group of stakeholders (Clarkson, 1995), a major change from Friedman's view on firms and profits. Kitzmueller and Shimshack (2012) synthesise diverse strands of the literature on CSR and contend that although CSR can achieve a second-best level of public goods provision, a concisely defined CSR can produce greater welfare than public or private provisions. Furthermore, the paper states that "the match of preferences between shareholders and stakeholders motivates different models with different implications" (ibid, p.78). This is true in the case of IFIs, where stakeholders are motivated by profit maximisation based on Islamic law, a model based on normative aspects of CSR, different from the usual ones based on 'instrumental considerations' as suggested by Margolis and Walsh (2003). The ethical identity marks IFIs as culturally distinct organisations aiming for profit maximisation based on Islamic principles rather than on market principles.

In a conventional company, agency theory highlights the complexity of contractual relations among different interest groups, particularly between owners and managers. The majority of IFI stakeholders are deeply concerned that their funds are invested in a Shari'ah-compliant manner (Chapra and Ahmed, 2002). If IFI managers behave very differently from the ethos of shareholders, and make investments which are not Shari'ah compliant, potential agency problems arise. In addition, the agency problems could escalate, with the separation of cash flow and control rights for depositors and investors (Safieddine, 2009). The view is that the traditional governance mechanisms to protect the shareholder's interest might not be 
sufficient in the case of IFIs. To mitigate agency problem, IFIs are expected to provide reliable information through regular and transparent financial reporting systems (ibid).

Our focus in this paper is two-fold: (1) to understand management perceptions of CSR in IFIs; and (2) to understand the extent to which IFIs follow in practice the ethical and social objectives implied by Shari'ah. This study is based on IFIs in Bahrain, which has two-thirds of the Islamic banks of the Gulf Cooperative Council states (GCC). Globally, the GCC states account for a high percentage of Shari'ah-compliant global financial assets (Wilson, 2009). Other than Islamic banks, Bahrain has eleven Islamic insurance companies (takaful) and has a significant presence in the market for Islamic Securities (sukuk) (IIBF). Bahrain is also host to a number of key organisations in Islamic Finance such as the Accounting and Auditing Organisation for Islamic Financial Institutions (AAOIFI), which sets standards for Islamic accounting and financial reporting among IFIs. The other major institutions in the region are the General Council for Islamic Banks and Financial Institutions (GCIBFI), the International Islamic Financial Market (IIFM) and the Islamic International Rating Agency (IIRA). The presence of these guiding organisations and the pro-active approach of the Central Bank of Bahrain make the country the natural hub for IFIs in the region.

The paper is organised as follows. First is a discussion on the fundamentals of CSR in IFIs. Next is a description of the research method used in the paper. The third section presents our results and analysis, followed by conclusions and implications.

\section{CSR Fabric in IFIs}

IFIs expect to follow ethical practices in compliance with Shari'ah principles which insist on lawful transactions and prohibit interest and speculation in business transactions. Shari'ahcompliant financial products are the foremost feature of IFIs. These institutions conform to Islamic principles which are universal, and broadly agree with most of the CSR agenda as codified in the UN Global Compact and even exceed the UN requirements in the developing human capital and transparency in business transactions (Williams and Zinkin, 2010). In many ways, the CSR aspect of Shari'ah principles is grounded in the shared religious obligation of IFI stakeholders which may not be achieved at an individual level (Farook, 2001). According to Al-Gazzali, a scholar in the 11th Century, the purpose of Shari'ah is "to 
promote the welfare of the people, which lies in safeguarding their faith, their lives, their intellect, their prosperity and their wealth" (cited in Kamla, 2005, p, 112). The principles of social justice and the well-being of society are central to the Shari'ah principles, and are obviously reflected in defining the social responsibility of IFIs, which differentiate these institutions from their conventional peers.

Islam defines private ownership of resources in a distinctive manner. Although individuals are accepted as trustees of their own resources, the resources must be utilised for the benefit of all human beings in an equitable way. The view is that, more than a religion, Islam is an organisation for society and its institutions, as well as a guide for the conduct of individuals within that institutional and social context (Tinker, 2004). The trusteeship demands the spreading of justice, truth, good deeds and virtue by humankind (Al-Quradaqi, 2000), based on individual responsibility to the community, advanced on the foundations of khilafah (fundamental unity and brotherhood of mankind) and justice (Chapra, 1992). However, Islam recognises the contribution of individual initiatives and self-interest through profit and private property, which are instrumental for efficiency and growth (ibid). The market or state will not succeed without abundant individual efforts within the limits of social welfare. These principles have an enormous impact on individual and macro-business activities.

In Islam, Riba (interest) is regarded as a prominent source of unjustified advantage (Sarker, 2000), and is cited in the Holy Qur'an as: "But Allah has permitted trade and has forbidden interest" (The Holy Qur'an: 2: 275). Riba causes unfair distribution of income in favour of the lender who has a guaranteed return on his capital without taking any risk. It is perceived as a form of oppression, unfairness, exploitation, and can cause damage to the economy (Ward, 2000). There is an approach to productive wealth in Islam which obliges its circulation without usurious transactions (Chapra, 1992). Thus, the prohibition of interest at extortionate rates aims at a shared risk between the lenders and the entrepreneurs which does not impede a rate of return on investment. This rate is not fixed and is built on contracts drawn on equity participation, profit-sharing (Mudaraba) and profit and loss sharing (Musharaka). Although the profits are shared in a mutually agreed manner, the financial loss is fully born by the investor, except in extreme situations of negligence or misconduct by the lenders (Aggarwal and Yousef, 2000). However, in practice, there is a view that investment 
account holders in IFIs have limited rights, and are exposed to higher agency costs than their counterparts in conventional institutions.

Zakah, charities, donations and Quard al-hassan are the major financial transfers appropriate to the social responsibility of IFIs. Shari'ah laws insist on the religious tax Zakah, which is one of the five pillars of Islam. This capital levy is payable once a year on any productive asset that has been possessed for the Zakah period (i.e. one lunar year). Zakah payment is obligatory on Muslim individuals and businesses subject to fulfilling certain conditions and after deducting the debts and needs of those individuals and businesses, but insists on a share for the community of the generated wealth. The responsibility for collecting and distributing Zakah, generally falls on Islamic states, but where this is not the case, individuals and businesses are still obliged to pay it for the welfare of the community (Maali et al., 2006). In practice, there are insufficient macro-level mechanisms for collecting Zakah, which goes against the mandate on sharing wealth given by the Holy Qur'an ${ }^{1}$. However, IFIs are in a unique position to fill the gap on shared religious obligation ${ }^{2}$ in mobilising Zakah.

Charity and donations are voluntary payments encouraged by Islam for social activities and are not an obligatory payment like Zakah. The IFIs have a separate entry for Zakah and Charity in their annual reports; this is to explicitly reveal the broader attitude of the institutions to social welfare. The other related payment for social benefit e is Quard alhassan, a loan to individuals who are in difficulty. Disclosure of the amount advanced under each category of financial help, for social welfare, financing of these schemes within an institution (institutional resources or depositors' funds) and the policies concerning those who are unable to pay back, are important information for IFI stakeholders; annual reports are expected to reveal these practices explicitly. Debtors are an area of concern for any financial institution. However, Shari'ah requires the lender to defer or even forego the collection of debt. The stakeholders would expect to know the details of treatment of insolvent clients by IFIs, and whether it is in accordance with Shari'ah rules.

\footnotetext{
${ }^{1}$ The Holy Quran says that "in their wealth there is a certain portion for those who ask for and for those who are in dire need" (Qur'an: 70:24, 25).

${ }^{2}$ A study of 32 Islamic Banks reveals that the majority carry out Zakah (IIIT, 1996; cited in Maali et al., 2006).
} 
In Islam, the issue of the natural environment has an inherently ethical basis (Williams and Zinkin, 2010). According to the Holy Qur'an, Nature belongs to Allah and as vicegerents of Allah, individuals have a duty to protect land and natural resources. In Islam, the agency known as Hisba which acted as an environmental regulator has declined in prominence with the emergence of market-based development strategies based heavily on the exploitation of natural resources (ibid). IFIs need to be cautious in identifying projects which might have an adverse impact on nature and society. However, despite rising incomes, modern-day businesses have a better awareness of the consequences of degrading environmental quality, and possible impact on human welfare, which has put Islamic values on the environment much closer to business practices. The other area which is central to the CSR fabric of IFIs is their relation with employees. Studies are consistent about the nature of major disclosure requirements under this category: payments (wages and bonuses) education and training for employees, equal opportunities and working environment (Maali et.al 2006; Haniffa, 2001).

The principles of financial assistance and the prohibition of Riba provide a firm foundation for the CSR framework of IFIs. In general, this discussion informs the immense value base of IFIs which has the potential to enhance and implement CSR principles in practice. However, the gap between the teaching of Islamic principles and their practice is significant in many Islamic countries, particularly on equality and basic human rights (Beekun and Badwai, 2005; Williams and Zinkin, 2009), and this may also have consequence for IFIs. We attempt to understand this gap between principle and practice from two perspectives: senior managerial perceptions of CSR in IFIs; and the actual reporting of CSR in the annual reports of IFIs.

\section{Research Methods}

\section{Interviews}

The interview strategy was aimed at understanding the perceptions of managers in IFIs, in order to inform our analysis of the nature and practice of CSR in these institutions. We conducted 18 in-depth semi-structured interviews with senior executives in nine IFIs operating in Bahrain. The senior executives were selected for their overall knowledge of Islamic banks, including strategic objectives which might have implications for CSR (Belal and Owen, 2007). The primary objectives of these interviews were to acquire detailed insights into the perceptions of IFI management toward CSR, particularly whether the Islamic principles have been translated into practice. 
The interviews were guided by a small set of open-ended questions, which allowed further discourse between interviewees and the researcher. This method helped us to understand managers' 'construction of reality' at a "depth which addresses the rich context that is the substance of their meanings" (Jones, 1985, p.46). Interviewees' names and contact details were obtained from the annual reports and the companies' websites. Initial contact with these institutions was made through formal letters addressed to company secretaries. The initial population for this study comprised all banks that claim to operate on an Islamic basis, identified from GCIBF. Seven responses were received from IFIs and two from regulatory bodies. These institutions are Albaraka Islamic Investment Bank, Takaful International, Arcapita Co, Bahrain Islamic Bank, Gulf Finance House, Kuwait Finance House, Bahrain, Capivest, AAOIFI and GCIBF. As explained in the introduction, the last two are key apex organisations in Islamic finance based at Bahrain. A brief profile of the interviewees showing their demographic background, status and nature of their organisation is given in Table 1.

After securing an appointment, background notes on the research and interview were sent to the interviewees in advance. Furthermore, participants were assured that their names and their organisation's details would not be disclosed when quoting them. Each interview ranged from an hour to an hour and a half. With the permission of interviewees, an audio recorder was used to record each interview. We opened the discussion by asking interviewees whether they knew CSR, then rolled out the questions on various issues for more specific comments. An interview guide containing a list of questions was prepared prior to the interview process, with two major sections: the motivation for CSR, and the activities of CSR.

Writing up the transcript was done in the same language as the interviews. Where this was in Arabic, the researcher translated the documents into English and cross-checked their accuracy with another translator to make sure that the translation was a true reflection of the interviewee's meaning. Although no variations were found, the procedure generated over 70 pages of data. 
Table 1: List of interviewees

\begin{tabular}{|l|l|l|l|l|}
\hline Interviewee no. & Position & $\begin{array}{l}\text { Nature of } \\
\text { organisation }\end{array}$ & Education & Gender \\
\hline I1 & Executive manager & IFI & BA & Male \\
\hline I2 & Executive manager & IFI & MBA & Male \\
\hline I3 & Senior manager & IFI & MSc & Male \\
\hline I4 & Senior manager & IFI & BA MSc & Male \\
\hline I5 & Financial controller & IFI & BA & Male \\
\hline I6 & Senior manager & IFI & BA & Male \\
\hline I7 & Executive director & IFI & BA, MBA & Male \\
\hline I8 & Executive manager & IFI & BA CPA & Male \\
\hline I9 & Corporate secretary & IFI & PhD & Male \\
\hline I10 & Manager & IFI & BA, CFA & Male \\
\hline I11 & Senior Manager & IFI & BA CPA & Male \\
\hline I12 & Senior Manager & IFI & BA & Male \\
\hline I13 & Executive Director & IFI & BA & Male \\
\hline I14 & Senior Manager & IFI & MSc CPA & Female \\
\hline I15 & Executive Director & IFI & PhD & Male \\
\hline I16 & Executive Director & IFI & BA & Male \\
\hline I17 & Executive Director & CIBAFI & PhD & Male \\
\hline I18 & Manager & AAOIFI & PhD & Male \\
\hline
\end{tabular}

We employed Miles and Huberman's (1994) approach in the analysis of transcripts through classification of the interview content by identifying substantive points and putting them into categories. The analysis process started with each transcript being identified by a code. Considering the broad questions in the interview guide, the researcher read all the transcripts repeatedly and highlighted substantive statements deemed relevant to the research focus. After going through all the transcripts, the researcher went read them through again while listening to the tape, in order to find any statements and intonations that he might have failed to highlight.

The previous stage resulted in a comprehensive representation of statements from the interviews, which required further decomposition. The following stage was therefore to derive a set of categories for the responses to each question from the highlighted statements and give them headings (Gillham, 2000). These categories and headings were checked against the highlighted statements and amendments were made. This procedure was repeated twice at different points of time to ensure that no categories and headings had been missed. Subsequently, a large matrix was constructed for each broad research question. Categories and headings classified under these questions were entered into the matrix. The researcher 
then went through the transcripts assigning each highlighted statement to a category. In addition, a second separate file was maintained to record overall observations on the meaning of the data for all interviews.

\section{Content Analysis}

Content analysis was employed to explore CSR practices in the case of the above seven IFIs for the years 2006-2010, whose annual reports for 2006, 2008 and 2010 were available in an English version on the Internet. Content analysis is a method of codifying the text into various themes depending on selected criteria, and deciding which documents were to be analysed (Krippendorff, 1980). Content analysis has been widely employed in CSR research (Gray, Kouchy and Lavers 1995) and is the most common method of analysing social and environmental reporting, particularly in firms (Milne and Adler 1999). Although CSR reporting can be made through a variety of channels such as advertising, promotional leaflets, company websites, interim reports and press releases, a substantial proportion of research has employed the annual report as the main data source of a company's attitudes toward social reporting. Moreover, in developing countries other disclosure channels have little use (AbuBaker and Naser, 2000), and the annual reports are the best source of information. The CSR content analysis literature does not provide a clear reference to themes of CSR reporting (Unerman, 2000), as most studies built their categories for analysis on the framework of previous studies (see, for example, Ernst and Ernst, 1978; Gray et al., 1995; Guthrie and Mathews, 1985; Guthrie and Parker, 1990; Hackston and Milne, 1996). This study drew on the literature on social and environmental disclosure from an Islamic perspective (e.g. Rice, 1999, Kamla et al., 2006; Maali et al., 2006; Haniffa and Hudaib, 2007; Williams and Zinkin, 2009; Aribi and Gao, 2010; Aribi and Gao, 2012) to design the key themes of CSR in IFIs (see Appendix 1).

In order to explore CSR reporting practices of IFIs in the form of an index, a Corporate Social Responsibility Index (CSRI) score is calculated. The approach to scoring items is essentially dichotomous in that an item in the research instrument scores one if communicated and zero if it is not (see Haniffa and Cooke, 2002; Haniffa and Hudib, 2007), and is additive and equally weighted to avoid potential scoring bias and scaling problems (Cooke, 1989). 
$\operatorname{CSRI}=\sum_{i=1}^{N} \frac{X_{i}}{N}$

Where:

$\mathrm{CSRI}_{j}=$ corporate social reporting index score for company $j$.

$N=$ number of items in the index

$\mathrm{X}_{i}=1$ if the item is disclosed

0 if the item is not disclosed

$0 \leq I j \leq 1$

\section{Findings and Discussion}

\section{Management perceptions of motivations for CSR}

There is significant support among managers for CSR, and recognition of the need for social and economic responsibilities of businesses to go together. As one manager (I7) contended, the core value of Islamic banks, besides making profit, is to share the aspirations of economic development and social justice. I7 went on to describe a project on affordable housing; although the profit margins were very low or almost nil, the IFI preferred to continue with this project to solve the housing problems of the low income population in the community. However, there is an opinion (I1) on maximising returns to shareholders among the respondents. Although this is a minority view, this subject clearly stated that IFIs are expected to generate profit, and are not charity organisations. Apart from this one case, all the other participating managers emphasised that profit does not constrain their CSR. Furthermore, there is an overwhelming agreement among the managers on the societal view of IFIs as players with responsibility to ensure socio-economic justice.

Religion seemed to be the primary motivation fuelling the recognition for CSR, as evident in the interviews. Most managers pointed out that since IFIs are set up with a religious motivation, the institutions are inclined to be ethical and socially responsible.

Islam encourages us to serve our society; therefore, it is part of our commitment as Muslims to be socially responsible. (I9) 
Our activities derived from Islam. Islam encourages us individuals and companies to help the other, give donation be socially responsible. (I2)

These views supported the argument that embarking on social responsibility from an Islamic perspective is not for financial or any other reward, but rather to gain God's blessing (Rice, 1999; Haniffa and Hudaib, 2007; Mohammed, 2007; William and Zinkin, 2009). In a way, the range of religious convictions has resulted as motivators of CSR (Hemingway and MaclaGan, 2004). The view is that an individual's accountability towards God encompasses his accountability to Umma (society) (Lewis, 2001). This notion was very common among managers, because it is increasingly clear that business needs to take into account the community in which it is operating (Jamali and Mirshak, 2007). The understanding of CSR among the managers in IFIs thus seems anchored in relation to the Islamic philosophy of conducting business within economic, legal and ethical dimensions.

\section{Management perceptions of CSR in practice}

Following the views on CSR, further questions were asked about CSR activities performed by their companies. Since the main objective of IFIs is to provide products and services that are Shari'ah compliant, IFIs serve the community as part of their commitment to social responsibility. There is a compelling view among most managers that Islamic banks are naturally inclined to be socially responsible due to their adherence to Shariah. The elimination of interest itself is considered an important part of adding value to society (I18). It was observed in the interviews that IFIs are under pressure to operate within the boundaries of Shari'ah, which strictly requires all transactions to be lawful (Halal) from an Islamic perspective, and avoids any unethical ones. Shari'ah committees are an exclusive feature of IFIs, supporting the CSR framework and making sure that IFIs are not moving away from Shari'ah principles.

Our business has to be in accordance with Shari'ah principle. For example, we had an opportunity of making a business deal last month, but we discovered that $1 \%$ of the total revenue from that deal would come from activities which contradicted Shari'ah morals, therefore the Shari'ah committee refused to approve the entire investment decision. (I9) 
There is a perception among the managers that Islamic banks fill two very significant positions in the community: religious and financial. On the religious side, Islamic banks take responsibility to comply with Shari'ah by offering Halal financial products and services, thus setting an example for people in the community who observe their activities. On the financial side, the banks' control of large funds and revenue helps them to undertake a social role. Thus, IFIs are supposed to serve the ethical needs of an Islamic society and undertake an important social function (Maali et al., 2006). One manager tried to elaborate the difference between IFIs and the interest-based banks in their method of conducting business and asserted that Islamic banks' commitments to CSR principles are reflected in their products and services.

The conventional banks receive deposits from the depositors and give them to the borrowers as loans or capital; they do not look at the reason behind the finance, which might be an unethical reason. However, in the case of the Islamic banks, it is important to know the reason for the loan, and where the loan is going to be spent, and ensure that the finance is being invested in a productive and ethical project. (I14)

In accordance with Islamic principles of social responsibility and justice, Islamic banks are expected to care for the less fortunate in society (Maali et al., 2006). Without exception, all managers consistently referred to the philanthropic activities of Zakah, donations and charity. There is a shared view (I14) that in addition to their making a profit, God has asked individuals to purify their money by paying Zakat and other voluntary payments. Unlike the payments of Zakah which are obligatory on Muslims, charity and donations are given by individuals and businesses on a voluntary, although strongly encouraged basis. Most managers mentioned that part of their CSR is helping the less fortune people in society and supporting charitable organisations through their dedicated charity accounts.

We have established an account dedicated mainly for donation and charity, and usually we transfer the non-Islamic income (defined by the Shari'ah committee) to this account to be spent in social activities and strictly not to be included in the bank's profit. We also make payments to some poor families on a monthly basis, and fund some charitable organisations on an annual basis. (I 16) 
Purely social loans such as Qard al-hasan are provided to help needy people who cannot borrow the money. The following quotations provide examples of the nature of the involvement by IFIs in these types of activity:

... the Qard al-hasan account receives donations from the bank and external donors, and its main purpose is to help the needy people by lending them money without any charge for a fixed period of time, and it covers expenses for education, medical treatment and marriage. (I 15)

IFIs may face financial arrangements such as Mudaraba and Ijarah, where clients are unable to pay their instalments. According to Shari'ah law, the lender is required to be lenient with the debtor, and an insolvent debtor should be granted a period of grace. However, we found a lack of disclosure related to banking policy toward its insolvent clients. In this regard, one manager stated that such a policy exists, but they do not disclose it:

The policy of Islamic banks is not to take any charge from insolvent clients if it was proved that the client was in financial difficulty situation ... However, to protect the bank side from dishonest clients, we may transfer the case to the court and charge the client if we find the client wants to deceive the bank. If we receive such charge, it has to be transferred to charity account .... We look to the insolvency client from a social point of view, especially if the client died and he or she owes the bank. (I14)

One of the interviewees (I7) gave a little more detail on how they dealt with similar situations. For instance, in one case, the client had a short-term Murabah contract with the bank, and faced difficulty in paying back the instalments. Following the request for a deferred payment, the bank decided to extend the period of payment based on an enquiry which proved that the delay was not because of the client's negligence. However, such a policy is not disclosed publicly in the annual report of IFIs, and one manager (I12) argued that disclosing such information would encourage moral hazard-type situations.

Overall, the interview results reveal that although the managers have a sound understanding of the motivations for CSR constructed on Islamic principles, this has not been translated adequately into practice. The narrow framework of Zakat distribution and other non-systemic 
philanthropic activities is dominant among IFIs, rather than any significant capacity-building efforts in communities (Asutay, 2008). However, we do not subscribe to these views, particularly on the proven impacts of direct cash transfers in the development literature, built on the "realisation that you cannot pull yourself up by your bootstraps if you have no boots" (Hanlon et al., 2010). Other than providing cash transfers, the IFIs also respond to the needs of their clients by rearranging the terms and conditions of loans. Some studies have noted a lack of CSR initiatives in IFIs (Dusuki, 2007; Hanifa and Hudib, 2007). According to the duty-based common-sense morality framework, institutions have special obligations towards closely related groups (Frederiksen, 2009), which is more likely in the case of institutions such as IFIs, instituted on the basis of religious principles. The 'special obligations' of IFIs may warrant more collective social welfare initiatives.

\section{Results of content analysis}

The second objective of this paper was to examine to what extent IFIs in practice, rather than in principle, actually honour the ethical and social objectives implied by Shari'ah. To tackle this, content analysis was employed to seek evidence of CSR as disclosed in annual reports. Table 2 presents the 3-year mean CSRI, the overall CSRI ranking by each bank and theme ranking based on seven observations for each theme. Table 3 presents the results of the CSRI for each theme for the three years examined in this study and the overall CSRI for each year by each bank. This shows clearly that the extent of CSRI by Islamic banks falls far short of our index. Those banks coming closest to meeting our benchmark were GFH, followed by Capivest and Arcapita which achieved second and third positions respectively. However, the level of information disclosed varies across the sub-themes.

Table 2: CSRI mean over the three years and ranking.

\begin{tabular}{|l|l|l|l|l|l|l|l|l|}
\hline Theme & BIB & GFH & Takaful & Capivest & Arcapita & AIB & KFHB & $\begin{array}{l}\text { Theme } \\
\text { rank }\end{array}$ \\
\hline Shari'ah & 0.13 & 0.80 & 0.2 & 0.60 & 1.00 & 0.6 & 0.20 & 2 \\
\hline Zakah & 0.80 & 0.80 & 0 & 0.60 & 0 & 0 & 0.60 & 3 \\
\hline $\begin{array}{l}\text { Charity and } \\
\text { donations }\end{array}$ & 1 & 0.66 & 0 & 1 & 1 & 1 & 1 & 1 \\
\hline Qard al-hassan & 1 & 0 & 0.5 & 0 & 0 & 0 & 0 & 4 \\
\hline Debtors & 0 & 0 & 0 & 0 & 0 & 0 & 0 & 6 \\
\hline Environment & 0 & 0 & 0 & 0 & 0 & 0 & 0 & 6 \\
\hline Employee & 0.33 & 0 & 0 & 0.22 & 0.11 & 0.33 & 0 & 5 \\
\hline $\begin{array}{l}\text { Overall rank by } \\
\text { each bank }\end{array}$ & 1 & 3 & 7 & 2 & 4 & 5 & 6 & \\
\hline
\end{tabular}


The theme on Shari'ah-compliant products and services by IFIs scored second in the theme disclosed ranking (Table 2). Table 2 also shows that all IFIs in the sample disclosed information about their Shari'ah compliance over the three years. The results showed that Arcapita and GFH have the highest CSRI, with the former getting full score with regard to this theme. The high number of IFIs disclosed under this theme was not startling since IFIs need to assure their stakeholders that all their activities and products comply with Shari'ah. The three-year mean CSRI ranges from 0.13 to 1.00 , suggesting variations and inconsistencies between the items among these banks. This finding is in agreement with those of Hanifa and Hudib, (2007) which show that the level of disclosure is inconsistent over the period of three years. Only four IFIs disclosed information on the nature and disposal of earnings prohibited by Shari'ah. For instance, GFH reports that interest from deposits in the Central Bank of Bahrain utilised for charitable purposes (GFH, 2006). 
Table 3: Annual CSR index

\begin{tabular}{|c|c|c|c|c|c|c|c|c|c|c|c|c|c|c|c|c|c|c|c|c|c|}
\hline \multirow[t]{2}{*}{ Themes } & \multicolumn{3}{|c|}{$\begin{array}{l}\text { Bahrain Islamic } \\
\text { Bank }\end{array}$} & \multicolumn{3}{|c|}{$\begin{array}{ll}\begin{array}{l}\text { Gulf } \\
\text { House }\end{array} & \text { Finance } \\
\end{array}$} & \multicolumn{3}{|c|}{ Takaful } & \multicolumn{3}{|c|}{ Capivest } & \multicolumn{3}{|c|}{ Arcapita } & \multicolumn{3}{|c|}{ Albaraka } & \multicolumn{3}{|c|}{$\begin{array}{l}\text { Kuwait Finance } \\
\text { House }\end{array}$} \\
\hline & 2010 & 2008 & 2006 & 2010 & 2008 & 2006 & 2010 & 2008 & 2006 & 2010 & 2008 & 2006 & 2010 & 2008 & 2006 & 2010 & 2008 & 2006 & 2010 & 2008 & 2006 \\
\hline $\begin{array}{l}\text { Shari'ah } \\
\text { compliance }\end{array}$ & 0.20 & 0.20 & 0 & 0.80 & 0.80 & 0.80 & 0.20 & 0.20 & 0.20 & 0.8 & 0.8 & 0.2 & 1 & 1 & 1 & 0.8 & 0.2 & 0.8 & 0.2 & 0.2 & 0.2 \\
\hline Zakah & 0.8 & 0.8 & 0.8 & 0.8 & 0.8 & 0.8 & 0 & 0 & 0 & 0.6 & 0.6 & 0.6 & 0 & 0 & 0 & 0 & 0 & 0 & 0.6 & 0.6 & 0.6 \\
\hline $\begin{array}{ll}\begin{array}{l}\text { Charity } \\
\text { donations }\end{array} & \text { and } \\
\end{array}$ & 1 & 1 & 1 & 1 & 0 & 1 & 0 & 0 & 0 & 1 & 1 & 1 & 1 & 1 & 1 & 1 & 1 & 1 & 1 & 1 & 1 \\
\hline Qard al-hassan & 1 & 1 & 1 & 0 & 0 & 0 & 0.75 & 0 & 0.75 & 0 & 0 & 0 & 1 & 1 & 1 & 0 & 0 & 0 & 0 & 0 & 0 \\
\hline Debtors & 0 & 0 & 0 & 0 & 0 & 0 & 0 & 0 & 0 & 0 & 0 & 0 & 0 & 0 & 0 & 0 & 0 & 0 & 0 & 0 & 0 \\
\hline Environment & 0 & 0 & 0 & 0 & 0 & 0 & 0 & 0 & 0 & 0 & 0 & 0 & 0 & 0 & 0 & 0 & 0 & 0 & 0 & 0 & 0 \\
\hline Employee & 0.33 & 0.33 & 0.33 & 0 & 0 & 0 & 0 & 0 & 0 & 0.33 & 0 & 0.33 & 0 & 0 & .33 & 0.33 & 0.33 & 0.33 & 0 & 0 & 0 \\
\hline
\end{tabular}


Table 2 shows that Zakah ranks number three in the themes disclosed. We found that only four IFIs paid Zakah on undistributed profits. The three-year means CSRI range from 0.60 to 0.80. Although three IFIs disclosed the balance on Zakah funds, neither provided reasons for the balance, a finding similar to the results of Haniffa and Hudaib (2007). For the other banks, which are not required to pay Zakah on behalf of their shareholders, it is the responsibility of management to calculate the Zakah according to the guidelines provided by AAOIFI and disclose the amount due in respect of shareholders and depositors (AIB,2010).

All IFIs in the sample, with the exception of Takaful, disclose information on charity and social activities, and five of them have full CSRI scores. The high level of disclosure under this theme may be attributed to the notion that Islamic Banks are viewed as financial institutions with a social face (Mashhour, 1996, cited in Maali et al., 2006). IFIs control large funds and revenue, which helps them to undertake a social role in society (Maali et al., 2006); however, the contribution by the banks to their charity funds is low. We found a large proportion of the charity funds are from non-Islamic incomes which the banks dispose as charity (GFH annual reports, 2009; 2010).

The differences across themes and institutions raise serious challenges for IFIs in Bahrain. Chapra and Ahmed (2002) provided evidence that nearly $86 \%$ of depositors in Bahraini Islamic banks are prepared to withdraw their funds if those banks fail to operate in accordance with Shar'ia, and 30\% would withdraw their funds if there were rumours of poor managerial performance. The CSRI scores of four themes - Qard al-hassan, debtors, employees and environment - raise a set of challenges for IFIs. In the case of Qard alhassan, which provides loans to individuals in difficulty, we found that only two Islamic banks provided this loan, with mean reporting ranges of 0.50 to 1 by Takaful and BIB respectively. The theme on debtors includes information on banks' debt policy and activities. Surprisingly, we did not find any information disclosed on debt policy in the sample IFIs. However, such a policy is clearly stated in the Holy Qur'an as a way of dealing with debtors in difficult situations: "If the debtor is in difficulty, grant him time till it is easy for him to repay" (The Holy Qur'an, 2: 280). 
Furthermore, none of the IFIs studied shows any information regarding the environment. This is in contrast with the literature, where researchers such as Maali et al. (2006) and Haniffa and Hudaib (2007) suggested otherwise. This divergence may be due to the fact that the sample consists of financial institutions only, and that environmental issues may not be seen as a concern by this type of institution. The theme of employee score is another baffling result. Since human resources are an important asset of any business entity, why have IFIs given less importance to this? This category covers the policies on equal opportunity, wages, workplace environment, and training and development. Only three IFIs disclosed information under this category, with means for the three years ranging from 0.11 (Arcapita) to 0.33 (BIB).

The differences in the levels of disclosure across the themes need some discussion. Stakeholder theory by Freeman (1994) assumes that values are necessarily for business, and expects managers to articulate the shared sense that the created value brings its core stakeholders together. IFIs are value-based institutions and give due rights to each stakeholder, in accordance with their relative stake, which implies that "all stakeholders get what is just for them" (Ullah and Jamali, 2010). Attempts were made earlier to identify the relative importance of various stakeholders in IFIs. However, some of our results contradict this ranking. For instance, employees are considered as the most important category of stakeholder along with owners, by Beekun and Badwai (2005). Our results indicate a low score of 5 for employees - does this mean that employees are not a priority stakeholder among IFIs? The same concern is relevant to the lack of disclosure under the categories of environment and debtors, because of their eminence in Islamic principles. Irrespective of these puzzling trends, the high rank obtained by charities and donations for social activities is distinctive. Since these payments are voluntary in nature, the trend reveals a broader understanding of social welfare in IFIs. Furthermore, these sort of 'cash transfers' have been spreading across the world as a measure to reduce transaction costs in development projects, and the results imply that IFIs are following the new drift in international development. 


\section{Conclusion}

This study attempts to understand management perceptions of CSR and its disclosure in IFIs in Bahrain through interviews and content analysis. The distinct feature of IFIs is its social responsibility role in its operations, which differentiates these institutions from their conventional peers. The findings of the study revealed that IFIs in Bahrain fall short in the ethical and social objectives implied by Shari'ah principles. Nevertheless, the managers have a thorough understanding of CSR, although this is not reflected sufficiently in practice. This was confirmed in the content analysis through lower CSRI scores in the categories of employees, debtors and environment. There is significant evidence of voluntary financial transfers by IFIs, which implies a bigger voluntary role for these institutions in social welfare.

Globally, IFIs have been experiencing an exponential growth trajectory with a range of innovative financial products. Although IFIs have displayed scope for banking in accordance with faith, they require deeper integration with the real economy, particularly on disclosures. As Sheng and Sing (2012) observed, cooperation between conventional and Islamic systems is a sensible approach which will lead to a Pareto optimal increase in world welfare. In the era of financialisation of the Islamic finance industry, how to reconceptualise their role in social welfare and Shari'ah compliance is a challenge for IFIs. 


\section{Reference}

Abu-Baker, N., \& Naser, K. (2000). Empirical Evidence on Corporate Social Disclosure (CSD) Practice in Jordan. IJCM, 10 (3), 18-34.

Ahmed, N. (2004). Corporate Environmental Disclosure in Libya: Evidence andEnvironmental Determinism Theory. Unpublished PhD Thesis, Napier University, UK.

Alam, K. (1998). Islam, Ethics and Accounting Practices. Accounting, Commerce \& Finance: the Islamic Perspective Journal, 2(2), 67-85.

Aribi, Z.A. \& Gao, S. (2010). Corporate social responsibility disclosure: A comparison between Islamic and conventional financial institutions. Journal of Financial Reporting and Accounting, 8(2), 72-91

Aribi, Z. \& Gao, S. (2012). Narrative disclosure of corporate social responsibility in Islamic financial institutions. Managerial Auditing Journal, 27(2), 199-222.

Asutay, M. (2008). Islamic Banking and Finance: Social Failure. New Horizon, 169, 1-3.

Asutay, M. (2012). Conceptualising and Locating the Social Failure of Islamic Finance: Aspirations of Islamic Moral Economy vs the Realities of Islamic Finance. Asian and African Area Studies, 11(2): 93-113.

Baydoun, N. \& Willett, R. (1997). Islam and Accounting: Ethical issues in presentation of financial information, Accounting, Commerce and Finance: The Islamic perspective, 1(1), 125.

Baydoun, N., \& Willett, R. (2000). Islamic corporate reports. Abacus, 36(1), 71-90.

Belal, A.R. \& Owen, D. (2007). The views of corporate managers on the current state of, and future prospects for, social reporting in Bangladesh: An engagement based study. Accounting, Auditing and Accountability Journal, 20(3), 472-494.

Beekun, R. \& Badawi, J. (2005). Balancing ethical responsibility among multiple organizational stakeholders: The Islamic perspective. Journal of Business Ethics, 60(2), 131145.

Bhagwati, J (2011). Markets and Morality. American Economic Review, 101(3), 162-65.

Chapra, M. and Ahmed, H. (2002) Corporate Governance in Islamic Financial Institutions Occasional Paper No. 6, Islamic Research and Training Institute: Islamic Development Bank, Jeddah.

Chapra, U. (1992). Islam and the Economic Challenge, The Islamic Foundation. Leicester, UK. 
Clarkson, M.B.E. (1995). A stakeholder framework for analyzing and evaluating corporate social Performance. Academy of Management Review, 20, 65-91.

Cooke, T.E. (1989). Disclosure in the Corporate Reports of Swedish Companies. Accounting and Business Research, 19(74), 113-124.

Dusuki, A. W. 2007. The Ideal of Islamic Banking: A Survey of Stakeholders' Perception, Review of Islamic Economics, 11, 29-52.

Dusuki, A.W. (2008). What Does Islam Say about Corporate Social Responsibility? Review of Islamic Economics. 12(1), 2-28.

Ernst and Ernst (1978). Social Responsibility Disclosure: 1978 Survey, Survey of Fortune 500 Annual Reports, Ernst and Ernst, Cleveland, $\mathrm{OH}$.

EU (2011) A renewed EU strategy 2011-14 for Corporate Social Responsibility, COM(2011) 681 final, Brussels, 25.10.2011.

Farook, S. (2007). On corporate Social Responsibility of Islamic Financial Institutions, Islamic Economic Studies, 15(1), 31-46.

Frederiksen, C (2009). The Relation between policies concerning Corporate Social Responsibility (CSR) and Philosophical Moral Theories - an Empirical Investigation, Journal of Business Ethics, 93, 357-71.

Gambling, T. \& Karim, R. (1986). Islam and Social Accounting. Journal of Business Finance and Accounting, 13(1), 39-50.

Gillham, B. (2000). Case study research methods. London: Continuum.

Gray, R., Kouhy, R. and Lavers, S. (1995). Corporate social and environmental reporting: A review and a longitudinal study of UK disclosure. Accounting, Auditing and Accountability Journal, 8(2), 47-77.

Guthrie, J. \& Mathews, M. (1985). Corporate social reporting in Australia. Research in Corporate Social Performance and Policy. 7, 251-271.

Guthrie, J. \& Parker, L. (1990). Corporate social disclosure practice: A comparative international analysis. Advance in Public Interest Accounting, 3,159-176.

Hackston, D. \& Milne, M.J. (1996). Some Determinants of Social and Environmental Disclosure in New Zealand Companies. Accounting, Auditing and Accountability Journal, 9(1), 77-108.

Haniffa, R. \& Hudaib, M. (2007). Exploring the Ethical Identity of Islamic Banks via Communication in Annual Reports. Journal of Business Ethics, 76 (1). 
Hanlon, J., Barrientos, A. and Hulme, D. (2010). Just Give Money To The Poor: the development revolution from the Global South, Kumarian Press, U.S.A.

Hassan, A., \& Harahap, S. (2010). Exploring corporate social responsibility disclosure: the case of Islamic banks. International Journal of Islamic and Middle Eastern Finance and Management, 3(3), 203-227.

Jamali, D. and Mirshak, R. (2007). Corporate Social Responsibility: Theory and practice in a developing country context, Journal of Business Ethics, 72, 243-262.

Kamla, R. (2005). Social Accounting in Selection of Arab Countries: Critical and Postcolonial Perspectives. Unpublished PhD Thesis, Heriot-Watt University, UK.

Kamla, R. Gallhofer, S. \& Haslam, J. (2006). Islam, nature and accounting: Islamic principles and the notion of accounting for the environment, Accounting Forum. 30(3), 245-165.

Kitzmueller, M. \& Shimshack, J. (2012). Economic Perspectives on Corporate Social Responsibility, Journal of Economic Literature, 50(1), 51-84.

Krippendorff, K. (1980). Content Analysis: An Introduction to its Methodology. London: Sage.

Lewis, M. (2001). Islam and Accounting. Accounting Forum, 25(2), 103-127.

Maali, B., Casson, P. \& Napier, C. (2006).Social Reporting by Islamic Banks. ABACUS, 42 (2).

Margolis, J.D. \& J.P. Walsh (2003). Misery Loves Companies: Rethinking Social Initiatives by Business, Administrative Science Quarterly, 48, 268-305.

Milne, M. \& Adler.R. (1999). Exploring the reliability of social and environmental disclosure content analysis. Accounting, Auditing \& Accountability Journal, 12(2), 237-256.

Miles, M.B. and Huberman, A.M. (1994). Qualitative Data Analysis, 2nd ed.. Newbury Park, CA: Sage.

Rice, G. (1999). Islamic Ethics and the Implications for Business. Journal for Business Ethics. 18(4), 345-58.

Safieddine, A (2009). Islamic Financial Institutions and Corporate Governance: New Insights for Agency Theory, Corporate Governance: An International Review 17(2), 142-58

Sarker, M.A. (2000). Islamic business contracts, agency problem and the theory of the Islamic firm. International Journal of Islamic Financial Services, 1(2), 12-18.

Sheng, A and Singh, A (2012). Islamic Finance Revisited: Conceptual and Analytical issues from the perspective of Conventional Economics, Working Paper No. 430, Centre for Business Research, University of Cambridge. 
Suliman, M. \& Willett, R. (2003). Using Hofstede-Gray framework to argue normatively for an extension of Islamic Corporate Reports. Malaysian Accounting Review, 2(1).

The Holy Qur'an (1410 H), Mushaf Al-Madinah An-Nabawiayah the Holy Qur'an: English Translation of Meanings and Commentary, Mecca: King Fahd Holy Qur'an printing Complex.

Tinker, T. (2004). The enlightenment and its discontents: Antinomies of Christianity, Islam and calculative science. Accounting. Auditing and Accountability Journal. 17(3), 442-475.

Unerman, J. (2000). Methodological Issues: Reflections on Quantification in Corporate Social Report Content Analysis. Accounting, Auditing and Accountability Journal, 13(5), 667-680.

Ward, I. (2000), Islamic Finance in the Global Economy, Edinburgh University Press, Edinburgh.

Williams, G. \& Zinkin, J. (2010). Islam and CSR: A study of the compatibility between the tenets of Islam and the UN global compact. Journal of Business Ethics. 9(4), 519-533.

Wilson, R (2009). The development of Islamic finance in the GCC, Working Paper, Kuwait Programme on Development, Governance and Globalisation in the Gulf States. the Centre for the Study of Global Governance, London School of Economics. 


\begin{tabular}{|c|c|}
\hline Category/Themes & Sub-themes \\
\hline $\begin{array}{l}\text { Shari'ah } \\
\text { compliance }\end{array}$ & $\begin{array}{l}\text { compliance with Shari'ah in all products and services } \\
\text { nature of unlawful transactions (if any) } \\
\text { reasons for undertaking such transactions } \\
\text { Shari'ah Board's view on the amount of revenue or expenses from these } \\
\text { transactions } \\
\text { how the bank disposes of such revenue }\end{array}$ \\
\hline Zakah & $\begin{array}{l}\text { source of Zakah } \\
\text { amount of Zakah } \\
\text { beneficiary } \\
\text { balance of Zakah } \\
\text { reasons for non-distribution }\end{array}$ \\
\hline $\begin{array}{l}\text { Charity and } \\
\text { donation }\end{array}$ & $\begin{array}{l}\text { the nature of charitable social activities } \\
\text { the amount spent on these activities } \\
\text { the sources of funds }\end{array}$ \\
\hline Qard al-hasan & $\begin{array}{l}\text { source of funds allocated to Qard al-hasan by bank } \\
\text { source of funds allocated to Qarad al-hasan by donation } \\
\text { the amounts given to beneficiaries } \\
\text { the social purpose for which the funds were given }\end{array}$ \\
\hline Debtors & $\begin{array}{l}\text { the policy in dealing with insolvent clients/debtors } \\
\text { the amount charged as late penalty } \\
\text { the Shari'ah Board's opinion }\end{array}$ \\
\hline Environment & $\begin{array}{l}\text { environmental policy } \\
\text { lending policy } \\
\text { conservation of natural resources }\end{array}$ \\
\hline Employee & $\begin{array}{l}\text { the policy on wages and other remuneration } \\
\text { the policy on education and training } \\
\text { the policy on equal opportunities }\end{array}$ \\
\hline
\end{tabular}

